\title{
FutureJournal
}

\section{Brazilianness: a Look at the Multiple Faces of the Brazilian National Identity}

\section{Mariana Bassi Sutter}

Doctorate in progress in Business Administration from Faculty of Economics, Administration and Accounting (FEA) University of São Paulo (USP), Brazil

mbsutter@gmail.com

\section{Maria Laura Ferranty Mac Lennan}

Doctorate in progress in Business Administration from Faculty of Economics, Administration and Accounting (FEA) University of São Paulo (USP), Brazil

ferranty@hotmail.com

\section{Gabriela Pelegrini Tiscoski}

Doctorate in progress in Business Administration from Faculty of Economics, Administration and Accounting (FEA) University of São Paulo (USP), Brazil gtiscoski@gmail.com

\section{Edison Fernandes Polo}

PhD in Business Administration from the Faculty of Economics, Administration and Accounting (FEA), University of São Paulo (USP), Brazil polo@usp.br

\section{ABSTRACT}

Over the past few years, Brazil has been gaining visibility internationally due to its increasing role in the global context. This leads to the interest, from society and academics, to better acknowledge the elements that characterize Brazilian culture. Therefore, the objective of this research is to understand the representations of Brazil's image and the diverse meanings of the Brazilianness concept though different views. Although the discussion about Brazilianness is not new, there are many interpretations about the characteristics that comprise national identity and culture, as well as those that make it unique. This research articulates the theoretical discussion about the theme, exploring what has already been presented by other authors on diverse fields as anthropology, sociology, social sciences, management and other areas. As such, the essay was developed in order to gather and articulate some understandings on the theme specially grounded on sociology, literature and business studies, which is its main contribution. The perspectives we use to this end are Brazillianness in management; tourism and foreigner' view. This 


\section{FutureJournal}

study allows future studies with the use of the Brazilianness concept to managers and academics.

KEY-WORDS: Brazilianness. National Identity. Brazilian Culture. Brazil's Image.

\section{Brazilianness: a Look at the Multiple Faces of the Brazilian National Identity}

\section{RESUMO}

Ao longo dos últimos anos, o Brasil vem ganhando visibilidade internacional devido ao seu crescente papel no contexto global. Isto leva ao interesse, da sociedade e acadêmicos, em conhecer melhor os elementos que caracterizam a cultura brasileira. Portanto, o objetivo desta pesquisa é compreender as representações da imagem do Brasil e os diversos significados do conceito de brasilidade por diferentes pontos de vista. Embora a discussão sobre a brasilidade não é nova, há muitas interpretações sobre as características que compõem a identidade e cultura nacionais, bem como aqueles que a tornam única. Esta pesquisa articula a discussão teórica sobre o tema, explorando o que já foi apresentado por outros autores em diversas áreas como antropologia, sociologia, ciências sociais, administração e outras áreas. Como tal, o ensaio foi desenvolvido a fim de reunir e articular alguns entendimentos sobre o tema, especialmente fundamentado em estudos de sociologia, literatura e negócios, que é a sua principal contribuição. As perspectivas que utilizamos para este fim são Brasilidade em administração; turismo e percepção estrangeira. Este estudo permite o uso do conceito de brasilidade aos gestores e acadêmicos em estudos futuros.

PALAVRAS-CHAVE: Brasilidade. Identidade Nacional. Cultura Brasileira. Imagem do Brasil. 


\section{INTRODUCTION}

The study of the meaning of Brazilianness is a theme that arouses interest and curiosity. The interest originates from the increasing representativeness of Brazil in the global economic scenario (Cavusgil \& Kardes, 2013). Brazil is today an important receiver of direct foreign investment in the world (UNCTAD, 2011; MacLennan, Piccioli, \& Yamasaki, 2014). Besides the economic view, mega events like the World Cup 2014 and 2016 Olympics in Rio de Janeiro attract world's attention towards Brazil. The theme instigates the curiosity due to the idiosyncrasies of the Brazilian soul. Colonized by Portugal, Brazil is country like no other in Latin America. From this colonization, the country inherited not only a different language, but also deep cultural relations with Africa, given the significance that slavery has had in building the country's identity (Whitelegg, 2012).

The discussion about Brazilianness development and its implications is old, and it is the central theme of several studies, as mentioned below. However, the studies focused on the development and comprehension of the term and of the components of the Brazilian culture are undervalued. One of the reasons may be that the Brazilian people, as Schwarz (1987, pp. 29) analyzes, see themselves as "unauthentic imitators" copying the cultural life that they have and, thus, they may think that their origin is not worth studying. Schwartz (1987) defines this feeling as a malaise of the Brazilian people. For him, this Brazilian cultural experience has been subject for critical reflection since the independence era, and it has been examined in several ways, under the point of view of cosmopolitans, nationalists, romantics, naturalists, modernists, leftists and rightists, among others. Hofstede (1980), by his way, understands culture as a collective programming of the mind common to people in a determined milieu. He has operationalized a scale with four cultural dimensions that are intended to measure cultural distances among countries: power distance, individualism versus collectivism, uncertainty and masculinity versus femininity (Hofstede, 1980).

Some authors agree that the Brazilian culture and national identity are different from other peoples and countries' (Hofstede, 1980; Ortiz, 
2006; Schwartz, 1987). Bhabha (2003), Indian thinker, understands the concept of nationality as an instrument of affiliation, both socially and textually. For Burity (2002), the interest in the subject highlighted by contemporary social sciences is visible, and this same interest is also noticeable regarding the development of cultural analysis models. This author says that the search for the understanding of culture is a tendency that goes beyond the national territory and crosses language boundaries in western societies. However, accepting that the Brazilian people are different is not enough. The aspects that characterize the Brazilian culture must be understood (Ortiz, 2006).

Understanding the meaning of Braziliannes can also be a source of value for Brazilian products. Some authors argue that the use of cultural references from the five regions of Brazil in products can add value to them, representing potential opportunities for companies that seek to win international markets. Finestrali and Garrido (2010) suggest that the association of references of the Brazilian identity can be an efficient way to distinguish Brazilian products in international markets. Morace (2009) supports such remarks by affirming that Brazil presents values that are recognized worldwide and that can generate great opportunities to the country at the moment they are disseminated through products. Sebrae (2002) argues that the Brazilian diversity has a great potential of commercial generation. Therefore, the study and understanding of the concept of Brazilianness is more than mere curiosity or interest; it can also provide business opportunities for the country, its companies and its people. So, this essay intends to contribute filling this gap by discussing and articulating multiple views on the theme.

The main objective of this study is to propose a reflection on which elements characterize Brazilianness from multiple points of view. Therefore, this essay explores studies performed by other authors through deep literature review by the categories defined: Brazillianness in management; tourism and foreigner' view. Data was organized systematically through Pharr model (2005). As such, the research was developed as an essay and collects several points of view on the central theme, which is its main contribution. Important to point out that those Brazilianness attributes 
organized from literature can be used as a beginning point on researches about the use of Brazilian national image abroad.

In order to formulate a theoretical discussion about Brazilianness, some topics were reviewed in several areas of study. First, a general appraisal was conducted about Brazilian characteristic, Brazilian dimensions were organized and also its streigh and weaknesses. Secondly, we organized some ideas about Brazilianness regarding company management characteristics based on Hofstede's (1980) dimensions. The study follows with the use of Brazilianness in tourism promotion, Brazilianness under the foreigner's view and at the end we try to consolidate those ideas in a section called Elements of Brazilianness, closing the essay. At the end, some final considerations are highlighted. It is understood by the authors that those perspectives do not summarize or frame the theme; though we argue that proposing this reflection is by itself stimulating for Brazilian companies and people.

\section{THEORICAL DISCUSSION}

\subsection{BRAZILIANNESS}

Among the main studies about the Brazilian cultural references, the traditional works Roots of Brazil stand out. The author Sérgio Buarque de Holanda was one of the researchers that most influenced the search for understanding the Brazilian identity (Finestrali \& Garrido, 2010). Holanda (1971) highlighted two main characteristics of Brazilianness in his work: lack of hierarchy and idleness. For him the lack of hierarchy was inherited from the Portugual and their socio-political structure reflecting fragmentation and lack of social life cohesion in the Brazilian society. Finestrali and Garrido (2010) sustain that such characteristic is still present in modern Brazil, resulting in a heterogeneous and multifaceted country that is able to produce a wide range of manifestations that differ culturally; and having as an underlying concept called unity in diversity. Which, according to the authors, can be propagated by Brazilian companies abroad, through both public policies and brands and products. 
Resuming Holanda's notes (1971), idleness presents a tendency to negligence. In Finestrali and Garrido's opinion (2010), this idleness should not be understood under a negative perspective, as it can include the concept of a Brazilian lifestyle, also known as cheerful and hospitable, and be used in marketing programs by organizations. We note that those dimensions have reflects on management and tourism Brazilian features, that will be explained further in the text.

Another author that stands out on the study of Brazilianness is Gilberto Freyre. For Freyre (1995, pp. 4), in 1532 a "society with agrarian structure, economic exploitation based on slavery, and hybrid composition of Indians and, later, black people" was formed, which the author called Tropical America. Freyre (1995) emphasized in his studies the origins of the Brazilian culture by highlighting the general characteristics of the Portuguese colonization, as well as the roles of the Indians, the Portuguese colonizer and the black slave in the blended construction of the Brazilian society. Therefore, Brazilianness is a distinctive and specific way of being of the Brazilian people, a result of their history and social and cultural miscegenation (Freyre, 1995; 2009).

Martins (2002, p. 67) corroborates with Freyre's observations (1995; 2009) by mentioning that Brazilianess can be understood as "a set of identity meanings that are similar and conflicting at the same time." For this author, the study of Brazilianess in the intellectual field is not explored as it should be, and, even with the revaluation of Freyre's and Holanda's works, Martins (2002) believes that the intellectuals resist seeking a more specific understanding of the Brazilian culture. The latter says that the search for the feeling of nationalism in Brazil is, to this day, limited; this behavior originates from the "mercantilist and slave colonial experience", that is, because of the feeling of submission, which the author treats as the memory that is reproduced by "institutions of centralized power and a hierarchical logic of domination." (Martins, 2002, p. 82). Thus, Brazil is a country characterized by mixing races, demographic diversity and natural resources. Or it can even be patent hybridity, as shown by Lucas (2010), with respect to the concepts regarding the complex process of mixture of cultures. 
Contributing for the formalization of the elements that compose the Brazilian cultural identity, the anthropologist Roberto DaMatta (2001) tried, based on Social Anthropology - which embraces an open and relativized vision of society by comparison - to reflect on some aspects of the Brazilian society that are not valued by the population, in order to understand the elements that constitute the Brazilian nation. From this author's point of view, Brazil "is a country, a culture, a geographical location, internationally recognized borders and territory, and also a house, a piece of the ground embraced with the warmth of our bodies, a home, the memory and knowledge of a place with which one feels a special, singular and totally sacred connection" (DaMatta, 2001, p. 11-12).

In his studies, DaMatta (2001) focuses on highlighting the richness of the Brazilian culture plurality, valuing small "nations" within the same country and analyzing how they interrelate, forming a homeland, which agrees with Bastide's quotes (1980) about "cultural islands". For that, DaMatta (2001) analyzes the Brazilian identity through actions that are part of the human condition: how one should eat, sleep, work, reproduce and pray. Therefore, the author reflects on how such actions are performed by Brazilians: their routine at home, work and social life; the illusion of the racial relations (there is no formal racial classification, but there is prejudice); the cuisine and family life; the differences between the regular parties and Carnival (a moment of freedom and experimentation of excesses without guilt); the Brazilian way with a trickery touch and religiosity of the Brazilian people.

Debrun (1990) understands that, in Brazil, there is the possibility of a general interaction among regions, ethnicities and classes in cultural manifestations, such as Carnival, samba dancing and soccer. DaMatta (2001), therefore, believes that Brazil cannot be understood as a unit, but in a relational way, reaffirming the observations of other authors mentioned in this section. Finally, DaMatta (2001) argues that the Brazilian people should explore their ability to synthesize, relate and reconcile, to create zones and values comprehending hope, happiness and future, in order to use them in the different areas of life (culture, politics, religion, economy and interpersonal relationships). 
The diversity in the social ways and representations of Brazilians arouses the questioning about what are the Brazilian values. Morace (2009) lists the following as Brazilian values: the joy of living; spontaneity in human relationships; simplicity in daily life; access to an experience that offers happiness to all (Carnival). This author also considers the neutral values of the products, such as fresh consumption (exotic fruit, unknown in other places); the richness and variety of colors; the smiles and body sensuality; in other words, the simplicity of the environment and the people. The study made by Sebrae (2002) indicates that the Brazilian culture is receptive to the incorporation of various cultural manifestations without feeling threatened, because the multiracial and multicultural society is a singular feature of the national identity. The study also shows that Brazil is characterized by the "lack of specificity, "an innate feature of the country's cultural diversity and the geographical, climatic and historical conditions count as sources for the creation of elements that characterize the "Brazilian soul", giving the country a strong cultural nature.

The Brazilian identity is also different from the border countries. Brazil does not share the same language of the border countries and there are several expressions that resist the concept of Latinization. This is because the idea of Latinity homogenizes different countries to form an idea of Latin America which is opposed to an America that is not Latin (Mignolo, 2007). Whitelegg (2012), for example, reports a case of resistance to the merging of Brazilian identity with the Latin identity in the São Paulo Bienal. 
Table 1 - Dimensions of the Brazilian identity

\begin{tabular}{|c|c|c|}
\hline Dimension & Attribute & Characteristics \\
\hline \multirow[t]{4}{*}{$\begin{array}{l}\text { Harmonious } \\
\text { diversity }\end{array}$} & $\begin{array}{l}\text { Cultural } \\
\text { identity }\end{array}$ & $\begin{array}{l}\text { Multicultural; multiracial; beneficial miscegenation; "lack of } \\
\text { specificity". }\end{array}$ \\
\hline & $\begin{array}{l}\text { Solidarity and } \\
\text { relational } \\
\text { character. }\end{array}$ & $\begin{array}{l}\text { Importance of social relationships; people's repudiation of } \\
\text { individualism; life centered on social relationships, people's } \\
\text { connections and people-environment connection; hospitality towards } \\
\text { foreigners; cordiality; "human warmth"; loyalty; personality; respect } \\
\text { to friends; repudiation of isolation; the need to be friends with the } \\
\text { person with whom you do business. }\end{array}$ \\
\hline & $\begin{array}{l}\text { Syncretism and } \\
\text { religiosity }\end{array}$ & $\begin{array}{l}\text { Unitary idea of Brazil, projecting images of the Portuguese, Indian, } \\
\text { and Black people; multiple and integrated religiosity. }\end{array}$ \\
\hline & $\begin{array}{l}\text { Adaptability } \\
\text { and openness } \\
\text { to novelty }\end{array}$ & $\begin{array}{l}\text { The "Brazilian way", innate to the environment where the Brazilian } \\
\text { people are, seeking to harmonize contrasts, overcoming rules in a } \\
\text { way that does not characterize guilt. }\end{array}$ \\
\hline \multirow[t]{2}{*}{$\begin{array}{l}\text { Unitary image } \\
\text { and internal } \\
\text { diversity }\end{array}$} & $\begin{array}{l}\text { Elements } \\
\text { characterizing } \\
\text { a unitary } \\
\text { image }\end{array}$ & $\begin{array}{l}\text { Language; natural aspects (sun, nature, organic tropical country, } \\
\text { precious and semiprecious stones and woods); physical aspects } \\
\text { (brown or dark skin, sensuality and cult of health and the body); } \\
\text { psychological and behavioral aspects (hospitality, sociability, } \\
\text { abundance, generosity, sense of humor, joy, optimism, spontaneity, } \\
\text { creativity, openness to innovation); collective events aspects } \\
\text { (cultural pluralism, baroque, modernism, music - Bossa nova, Samba } \\
\text { and Carnival, soccer, Telenovelas and Capoeira). }\end{array}$ \\
\hline & $\begin{array}{l}\text { The specificity } \\
\text { problem }\end{array}$ & $\begin{array}{l}\text { Difficulty to configure a unitary image of Brazil due to the elements } \\
\text { that contribute for an extensive image of Brazil, through } \\
\text { geographical, cultural and social traits that are strongly connected to } \\
\text { specific local realities (Amazon rainforest, Pantanal, black culture, } \\
\text { indigenous culture, countryside culture, musical expressions of } \\
\text { specific regions). }\end{array}$ \\
\hline $\begin{array}{l}\text { Brazilianness } \\
\text { between the } \\
\text { tradition and } \\
\text { the } \\
\text { innovation }\end{array}$ & $\begin{array}{l}\text { Tradition and } \\
\text { Innovation }\end{array}$ & $\begin{array}{l}\text { A young country, Brazil is open and receptive to innovations. The } \\
\text { Brazilian tradition can be defined by its unlimited capacity of } \\
\text { adaptation, acceptance, recycling and adjustment to the new. } \\
\text { Brazilians, without considering potential implications, merge the new } \\
\text { with the tradition. }\end{array}$ \\
\hline \multirow[t]{3}{*}{$\begin{array}{l}\text { Appreciation } \\
\text { of the cultural } \\
\text { specificities }\end{array}$} & Nature & $\begin{array}{l}\text { Environments diversity and exuberance - rivers and waterfalls, } \\
\text { beaches, the sea, islands, wetlands, forests, woods - source of } \\
\text { tourism development, aesthetics and pharmaco-therapeutic quality. }\end{array}$ \\
\hline & $\begin{array}{l}\text { Prestige of } \\
\text { artistic } \\
\text { expressions }\end{array}$ & $\begin{array}{l}\text { Prestigious artists: literature (Guimarães Rosa, Machado de Assis and } \\
\text { Jorge Amado); poetry (João Cabral de Mello Neto and Carlos } \\
\text { Drummond de Andrade); cinema (Mário Peixoto and Walter Salles); } \\
\text { architecture (Oscar Niermeyer and Paulo Mendes da Rocha); painting } \\
\text { (Segall, Portinari and Antonio Dias); plastic arts (Helio Oiticica), } \\
\text { theater (Nelson Rodrigues) and popular music (Bossa Nova). }\end{array}$ \\
\hline & $\begin{array}{l}\text { Expressions of } \\
\text { collective life }\end{array}$ & $\begin{array}{l}\text { Several popular demonstrations, such as: northeastern forró, } \\
\text { beaches, the Carnival, street celebrations in Bahia, the Círio de } \\
\text { Nazaré festival in Belém, New Year's Eve in Rio de Janeiro, the great } \\
\text { musical events, Candomblé, and Catholicism manifestations. }\end{array}$ \\
\hline
\end{tabular}

Source: Authors, developed based on Sebrae (2002).

According to Sebrae (2002), the image of Brazil abroad will be valued only when the country perceives itself in a positive way, identifying the value of the characteristics of its people. In line with this notation, Ortiz 
(2006, p. 39) affirms that "the myth of the three races has not yet been ritualized, as the material conditions for its existence are only symbolic," understanding, therefore, that the value of the Brazilian mixed-race culture will be recognized only when the symbolic conditions are identified by its people and turned into material conditions.

\subsection{BRAZILIANNESS IN MANAGEMENT}

Among the elements of the Brazilian national culture, Caldas (2006) cites three main ones: 1 ) representation of the work hierarchy, which has its roots in the way the country was colonized; 2 ) the personification, that is, the idea that the social and organizational relationships are not regulated only by power, but also by personal relationships that surpass the organizational relationships; and 3) the ambiguity, which can be exemplified by the Brazilian way - the social practice that aims at finding a way to bend the rules. In this line of reasoning, DaMatta (2001) associates the Brazilian way with trickery. Srour (1994) refers to the Brazilian way as "smart practices" inspired by an ethos of opportunism.

Those cultural dimensions influence the study of Brazilianness regarding company management characteristics. That is because the companies' environment is not neutral; it has to comply with several social, political and symbolic determinations (Srour, 1994). Betânia Tanure, in her book Gestão à Brasileira (Brazilian-way of Management), discusses Brazilianness characteristics in the management and business world. As discussed in the previous section, there is a Brazilian identity that forms the national image with all idiosyncrasies and paradoxes. That is why it is important to understand how the national characteristics and specificities impact the company as a social microcosm, when assuming that the company is also a sociocultural environment (Srour, 1994; Tanure, 2005). Remembering that the Brazilian culture should be understood as a multiple and flexible social product, and not as a stable and homogeneous construct (Caldas, 2006).

Hofstede (1980) defines culture as a collective programming of the mind, which is common to people in a determined environment. In order to 
understand the national culture, a scale of four dimensions was defined: power distance, individualism versus collectivism, uncertainty and masculinity (Hofstede, 1980). These dimensions are very useful when discussing the Brazilian way of management. We acknowledge that other authors study cultural differences among countries (House, Hanges, Javidan, Dorfman, and Gupta, 2004; Schwartz, 1992). However Hofstede (1980) is broadly used under several topics of study (Chueke, Maclennan, and Borini, 2014; Ng, Lee, and Soutar, 2007).

The first dimension is power distance. Hofstede (1980) observes that in all societies there are inequalities. The difference is in the way each society addresses the diversity. Regarding power distances, Brazil presents a high indicator compared to the other countries surveyed by the author (Hofstede, 1980). This reflects its Latin characteristic, a legacy of the Roman Empire (Tanure, 2005). Caldas (2006) also understands that the hierarchical representation at work has its roots in the way the country was colonized. In this aspect, the Brazilian leaders are similar to French and Italian ones, and different from countries such as Germany, Denmark and Sweden. Culturally in Brazil the leaders centralize their decisions and are not used to consulting their subordinates when making a decision (Tanure, 2005). However, Tanure (2005) believes that it is possible to leave the paternalist position and build a relation of interdependence between leaders and their teams.

The second dimension analyzed by Hofstede (1980) is individualism versus collectivism. In individualistic societies, the bond among people is weak, with each one taking care of themselves and their immediate family. In collectivistic societies, on the other hand, the social relationships are extended and the individual becomes loyal to the group. In Brazil, the family has a very important role in the society, due to its paternalistic, rural and self-sufficient historic structure (Tanure, 2005). The Brazilian society can be considered collectivistic, where "we" prevails over "I", and the group has a great social value. DaMatta (1987) reminds that in Brazil a "person" is identified by their connections. The status of belonging to a determined group offers protection to its members and enables them to benefit from the "facility of the law." In Brazilian society, the personification concept is 
important. That is, the social and organizational relationships are not regulated only by power, but also by personal relationships that surpass the organizational relationships (Caldas, 2006). Srour (1994) argues that the personal relationships such as kinship, neighborhood, friendship and fellowship manifest itself organizationally in "informal networks of power." Another feature of the collectivistic society is the difficulty in saying 'no.' It represents a situation of confrontation and is rarely used clearly (Tanure, 2005). In Brazil, a political form of conciliation is predominant, not defined by mutual tolerance, but by a sort of forced co-optation, from the weakest to the strongest (Debrun, 1990). According to Caldas (2006), the singular way of addressing issues can be exemplified by the Brazilian way - social practice that aims at finding a way to bend the rules and solve conflicts.

Another analyzed cultural trait is the tolerance to uncertainty. This feature verifies the tolerance of the society to ambiguity and instability (Hofstede, 1980). Brazil presents a strong need to control the uncertainties, which is reflected on protective families and on the fact that teachers are expected to always have answers for the student's questions (Tanure, 2005). Societies with this characteristic tend to show emotions more clearly. In companies, this cultural feature leads to unwillingness to take risks, resistance to change and a desire to work in larger organizations that provide more security for their employees.

Finally, the last dimension is masculinity versus femininity. For Hofstede (1980), this dimension verifies how much a society values the traits considered masculine, such as assertiveness, competitiveness and materialism, over values such as quality of life and concern about other people and one's own children. Furthermore, this dimension qualifies the genres and roles of men and women in the society. In countries considered more "masculine," men and women's roles are more divided (Tanure, 2005). The Brazilian society is at an intermediate level in this dimension. In Brazil, a woman can work and achieve prominent positions in her career; however, she is still expected to look after the house and the family. Another aspect that differentiates masculine and feminine societies is the importance of the school performance. In more "feminine" societies, poor 
school performance does not have consequences as significant as in more "masculine" countries (Tanure, 2005).

Table 2: Brazillian cultural dimensions

\begin{tabular}{|l|l|}
\hline \multicolumn{1}{|c|}{ Dimension } & \multicolumn{1}{c|}{ Brazil 's characteristic } \\
\hline Power distance. & High centralization. \\
\hline $\begin{array}{l}\text { Individualism versus } \\
\text { collectivism }\end{array}$ & $\begin{array}{l}\text { Collectivistic, co-optation form the } \\
\text { weakest to the strongest. }\end{array}$ \\
\hline Tolerance to uncertainty & $\begin{array}{l}\text { Low, unwillingness to take riskis, } \\
\text { resistance to change and need for } \\
\text { security. }\end{array}$ \\
\hline Masculinity versus femininity & Intermediate. \\
\hline
\end{tabular}

Source: Authors based in Tanure (2005) and Hofstede (1980).

\subsection{BRAZILIANNESS IN TOURISM PROMOTION ABROAD}

Pires (2001) understands that the tourism product must fulfill a dream that starts out with the choice of a destination and is developed from the image tourists have of this destination. In face of the variety of factors that amazes tourists, disseminating the image of Brazil, with its cultural and religious diversity and variety of natural resources is a challenge. In January 2003, the Ministry of Tourism of Brazil was created, and, with that, the Brazilian Tourism Enterprise (EMBRATUR), which since 1996 was responsible for all the tourism policies, started focusing its activities on the promotion of Brazilian tourist destinations and products in the international market, and it was renamed Brazilian Tourism Institute, maintaining the same acronym - EMBRATUR (GOMES, 2012).

Other institution committed on understanding Brazillianess dimensions and image is Sebrae. For Sebrae (2002), the strongest and most evident Brazilian characteristics are valued in the construction of a positive image of the nation. This is, however, a complex task, as it implies in the definition of something very distinct and heterogeneous (SEBRAE, 2002). Sebrae (2002), then, used a model derived from the anthropological research, from which the most important traits of the Brazilian identity were classified, as follows: nature; material culture (collective adaptation, 
products and techniques used to accomplish them); social culture (economic manifestations, social differentiation, clustering, education, social relationships, time organization, rituals, social control); and the ideal culture (communication, awareness of nature, human being, regulation, values, forms of expression). The Casa Brasileira's study searched for the characterization of the Brazilian culture in several dimensions, denominated as natural and cultural heritage, in addition to the possibilities of appreciation.

We can note that some dimensions pointed by Sebrae can be also founded in management. One example is personhood, dimension referred as "collectivism" by Hofstede (1980). Such dimensions are summarized in Table 3.

Table 3: Strengths and Weaknesses of Brazilian Cultural features.

\begin{tabular}{|c|c|}
\hline Strengths & Weaknesses \\
\hline Racial and cultural pluralism; & $\begin{array}{l}\text { Low self-esteem, valorization only of what } \\
\text { comes from abroad, a result of the cultural } \\
\text { poverty; }\end{array}$ \\
\hline 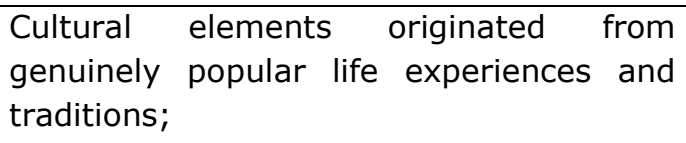 & $\begin{array}{l}\text { Lack of trust in the authorities and } \\
\text { government, and, consequently, general } \\
\text { distrust in public entities; }\end{array}$ \\
\hline Joy and optimism; & A certain contempt for technicalities; \\
\hline $\begin{array}{l}\text { Pluralist and syncretic characteristics of } \\
\text { the culture; }\end{array}$ & $\begin{array}{l}\text { The idea of malandragem, or trickery, as a } \\
\text { need to take advantage of everything, } \\
\text { specially of the humbler people; }\end{array}$ \\
\hline Emphasis on personal relationships; & $\begin{array}{l}\text { Lack of promotion of the Brazilian cultural } \\
\text { work in all segments; }\end{array}$ \\
\hline Hospitality and cordiality; & $\begin{array}{l}\text { Arrogant personhood, which places one } \\
\text { above the law; }\end{array}$ \\
\hline \multirow[t]{4}{*}{$\begin{array}{l}\text { Cultural, economic and technological } \\
\text { creativity; }\end{array}$} & $\begin{array}{l}\text { Conviction that everyone cheats to make } \\
\text { more money; }\end{array}$ \\
\hline & Ignorance as "profession of faith"; \\
\hline & $\begin{array}{l}\text { Dishonesty in the name of family and } \\
\text { friends; }\end{array}$ \\
\hline & $\begin{array}{l}\text { Lack of commitment regarding the } \\
\text { agreements signed. }\end{array}$ \\
\hline
\end{tabular}

Source: Authors based on Sebrae (2002). 
The attributes of Brazilianness are used to promote tourism and also sell Brazilian products abroad. In order to meet the National Tourism Plan, the Aquarela Plan was created in 2003, in order to develop a tourism marketing plan focused on the tourism and the country's image (MINISTÉRIO DO TURISMO, 2014). The time frame of the first edition of the plan was 2003-2006, and, then, 2007-2010. In order to continue the sixyear planning of the international tourism marketing, the plan was presented to up to 2020 . The main objective of this plan is to establish aims and objectives to prepare the country to host the two major sports events of the world - The 2014 World Cup and the 2016 Summer Olympic Games (MINISTÉRIO DO TURISMO, 2014).

According to Gomes (2012), the Aquarela Plan was developed from the Program to Reposition Brazil's Image abroad, which is part of the Macro-Program of Promotion and Support for Marketing, within the National Tourism Plan (2003-2007). One of the Aquarela Plan action lines is to update the image the world has of the country, as the foreigners that have already visited Brazil have a different opinion about the country than the tourists that have not visited Brazil yet (MINISTÉRIO DO TURISMO, 2014). Therefore, in 2005, the Brasil Brand was launched (Gomes, 2012; Mariutti \& Giraldi, 2012) and, currently, the Brasil Brand Manual is in its second issue, which was prepared by a group of designers, marketing and advertising professionals with the objective of disciplining the use of the image of Brazilian tourism represented by the Brasil Brand symbol (MINISTÉRIO DO TURISMO, 2010). The concept that supports the Brasil Brand is the set of the following attributes: joy; sinuosity/curves (of nature, of people's character); luminosity, brightness and exuberance; mix of culture and races; modern and competent (MINISTÉRIO DO TURISMO, 2010).

However, it is important to realize, when promoting the national Brand, to the attributes disclosed abroad. Kajihara (2008) highlights that EMBRATUR has reinforced along the years some stereotypes about Brazil, as carnival, soccer and the sensuality of Brazilian women. These attributes have not always contributed for the development of a positive image abroad, as the propagation of these attributes has had consequences in society, such as strengthening the depreciation of women, the search for 
sex tourism and child prostitution by part of foreign tourists visiting the country (Kajihara, 2008). In this direction we suggest that Brazilianness concept be used thrifty once not all image is positive, as not all kinds of tourism may be encouraged.

\subsection{BRAZILIANNESS UNDER THE FOREINER 'S VIEW}

Understanding Brazilianness under the foreigner's view is not easy, due to the variety of points of views. Therefore, this section addresses the image of Brazil under three perspectives. Firstly, the study discusses the sociological perspective, based on Bastide's studies (1980). Then we present Dutch students' view of Brazil, from the Netherlands. (Girladi, Giraldi \& Scaduto, 2011). Following, the point of view of foreigners in Brazil is reviewed through a study with foreign exchange students in a university in Brazil, (Telles, 2012). In addition to the students' point of view, we access tourists views (Caponero, 2007; O’Neil, 2006), and also the findings about Brazilianness through a research with international fashion buyers are also brought into discussion (Sutter, 2013; Sutter, Polo, \& Maclennan, 2014). Finally, from a wider perspective, we present the results of Mariutti and Giraldi' analysis (2012) about the Anholt Nation Branding Index, which assesses a country's image. Each person perceives and understands the country's identity under their perspective.

One foreign researcher who was dedicated to understand the history and formation of the Brazilian culture while living in the country was the French sociologist Roger Bastide. In his work Brazil, Land of Contrasts the author sought to reproduce the Brazilian plurality in several ways, claiming that the country is composed of three different types of Brazil: "The Indigenous Brazil of the Amazonia, Mato Grosso and Goiás states; the Southerner white Brazil; and the black Brazil of mainly the Northeastern coast" (Bastide, 1980, p. 68). Bastide (1980) adds other countries to the discussion of the Brazilian cultural plurality, such as France, for its intellectual connections, and Italy, due to the immigrants. The author also suggests that Brazil has an important position in the global context, and that it should occupy the space between the Anglo-Saxon and the Slav 
world, because it is a young republic that managed to join, in syncretism, several civilizations (Indian, African and Portuguese.)

Therefore, Batiste (1980) reinforces the observations of Freyre (1995; 2009), Finestrali and Garrido (2010), Martins (2002) and Holanda (1971) by arguing that Brazil can be seen as an "archipelago of dissimilar cultural islands, although bathed by the same waves, and crowned by the same stars" (Bastide, 1980, p.209), a nation that combines elements of the indigenous, African and European cultures, originating the myth of the three races (Ortiz, 2006).

In order to extend the understanding about how Brazil is comprehended abroad, Giraldi et. al. (2011) conducted a research to understand which image the Dutch students have about Brazil. The study shows the words that came to interviewees' minds when they thought of Brazil, and these answers can be clustered under the following categories: population, politics, nature, sports and economy. For such students, Brazil's image regarding the population consists of three subcategories: culture, women and receptiveness. The culture subcategory addresses Brazilian food and Carnival. The women are related to the sensuality and the beauty of the Brazilian women. The receptiveness subcategory includes the attributes related to the Brazilian people's affectivity and hospitality. Regarding the Nature category, the interviewees listed beaches, the climate and natural beauties. Regarding politics, they mentioned corruption, social inequality and violence as elements that form the country's image in this perspective. As for the sports category, they named idols, such as Ayrton Senna, and Brazilian soccer. Finally, when asked about the economy, they mentioned the Brazil's rise in the global scenario and the products (Giraldi et al., 2011). In this line, characteristics related to country extension are addressed by Caponero (2007) when studying Brazil's image in Italy. The author, when analyzing the promotion of Brazilian tourism in Italy, points out that Brazil is remembered as a country of continental dimensions, owner of a wide variety of beaches, the Amazon forest and the Pantanal. Therefore, Brazil's greatness is associated with territory extension, abundant fauna and flora, natural richness and ecological diversity. 
In a research with British tourists, O'Neil (2006) sought to understand what are the expectations that visitors have on choosing Brazil as a touristic destination. According to such research, in line with Caponero's findings (2007), the landscapes and natural beauties have great appeal to this public, followed by the positive cultural characteristics of the Brazilians. The research showed that the beaches and the sun are the most important images that tourists have of Brazil, followed by the people's cordiality and culture. It is interesting to note that the visitors leave the country with a better image than the one they had when they arrive, regarding the negative aspects of prior knowledge, such as criminality and unsafety (O'neil, 2006), aspects that can be understood as stereotypes associated with Brazil.

It is relevant to compare these opinions to those of international students in Brazil. In a research with foreign exchange students in Brazil, Telles (2012) found that the cultural heritage and natural beauty are the main factors that aroused interest in the country. These factors were followed by the economic importance, scientific production, industrialization level and available tourism options. For the foreign exchange students, the main associations with the country are soccer, carnival, the sun, beaches and having fun; followed by violence and poverty. The study concludes that the promotion of the Brasil Brand benefits the foreign exchange offer to the European public. That is because knowing the culture, learning Portuguese, and Brazil's image were considered important elements in choosing foreign students to visit the country for exchange (Telles, 2012). Such study strengthens the importance of EMBRATUR's efforts in promoting Brazil's image abroad.

Sutter's et al. study (2014) presented a similar result to Telles' findings (2012). They sought to understand Brazilianness in fashion by interviewing foreign international fashion buyers from France, Colombia, Peru and England. The interviewees mentioned the following elements as particular of Brazil's image: sensuality, nature, beaches, climate and natural beauties; Brazilian women; economic rise; joy of living, spontaneity in human relationships, simplicity in daily life; affectivity, hospitality and solidarity. 
Another study quantitatively assessed Brazil's image based on the Anholt Nation Branding Index, a brand-country indicator designed by a British researcher in 2006. In order to develop such indicator, Simon Anholt conducted a field research in which 20000 people answered a questionnaire in order to measure a country's reputation on the perceptions of six dimensions in 50 cities of 20 countries (Mariutti \& Giraldi, 2012). Mariutti and Giraldi (2012) analyzed the perception of four countries among the ones that send more tourists to Brazil - China, United States, United Kingdom and Japan - regarding six variables used by the Index, as follows: People, Products, Government, Tourism, Culture and Immigration, and Investment. According to such analysis, the culture dimension had the lowest score (13\%). This dimension addresses the foreigners' perception regarding aspects of contemporary culture, such as, movies, music, arts, sports and literature. However, it is adequate to remember that Telles (2012) and Pires (2001) highlighted the importance of the cultural and historical aspects of Brazil in the foreigner's destination choice. As previously analyzed (Table 1), Brazil is a country rich in cultural manifestations (DaMatta, 2001; SEBRAE, 2002) with emphasis on literature, poetry, architecture and music. Therefore, the importance of highlighting the Brazilian cultural aspects in promotional actions conducted abroad is strengthened.

Mariutti and Giraldi's study results (2012) showed that the country, among the researched ones, with the best perception of Brazil's image is Japan, followed by the United Kingdom, United States, and, then, China. An interesting finding of the authors is that the construction of a country's image is interrelated to tourism, which has direct connections and relations with the following variables: government, immigration and investment, and with people who participate actively to support the tourists (Mariutti \& Giraldi, 2012), reinforcing, once again, the importance of EMBRATUR's effort to promote Brazil's image in other countries.

We note that elements from foreigners view repeat characteristics already seen in other dimensions. For instance, nature, beaches and natural beauties were already pointed by EMBRATUR (MINISTÉRIO DO TURISMO, 2014), as note by Sutter et al. (2014). The economic perspective is also 
seen in the study made by Sebrae (2002). Also spontaneity and affectivity can be related to collectivism and femininity, features shown in the session about management. So, we see in our study that national characteristics affect many perspectives of Brazilian lifestyle.

\section{RESULTS: ELEMENTS OF BRAZILIANNESS}

From the analyzed literature, the objective of this section is to organize the main characteristics that comprise Brazilianness into lines or dimensions. In order to structure this analysis, the holistic model proposed by Pharr (2005) about the country of origin is used. In this model, the author set principles used in the evaluation of a country: stereotypes about the country, demographic aspects, ethnocentrism, Hofestede's cultural dimensions and level of economic development of the country.

The stereotypes represent the cognitive expectations of the individuals within a social group. Therefore, the national stereotypes can be understood as the characteristics associated with a nation's people or products, whether these characteristics are accurate or not (Schneider, 2005). The stereotypes can be negative or positive (Niss, 1996), created from cognitive and affective aspects that influence assessments about the country and its products (Challatas, Kramer \& Takada, 2008). We note that the liberal view is pointed out since DaMatta (2001), Holanda (1971), and Debrun (1990) on their talk about carnival and freedom. Srour (1994) explains his view about "jeitinho", a characteristic that also shows freedom on bending rules and norms. This feature may be considered positive by authors as Tanure (2005) and others. However we note that all comes from the same origins. In this sense, carnival, freedom and flexibility in business are cultural characteristics deeply rooted in Brazilian soul.

Demographic aspects include the geography in addition to the people's characteristics, such as racial and religious plurality (Kotler \& Getner, 2002). Ethnocentrism, which is the belief of the superiority of one culture over another, is also presented in this analysis (Pharr, 2005). The cultural dimensions should also be considered, based on the dimensions established by Hofestede (1980), used in the understanding of the national 
culture influence, especially in the particular management practices of each country. Finally, the level of economic development of the country addresses the way the country is perceived in the global context. Table 4 consolidates this research's findings about Brazilianness based on the Pharr model (2005).

Table 4 - Brazilianness under several views

\begin{tabular}{|c|c|}
\hline Lines & Brazilianness Characteristics \\
\hline Stereotypes & $\begin{array}{l}\text { Idleness, hospitality (Holanda, 1971; Giraldi et al, 2011), joy } \\
\text { (Holanda, 1971; Caponero, 2007; Morace, 2009; MINISTÉRIO DO } \\
\text { TURISMO, 2010); sexual objectification of women, sexual tourism, } \\
\text { child prostitution (Kajihara, 2008); samba, soccer and carnival } \\
\text { (Debrun, 1990; SEBRAE, 2002). }\end{array}$ \\
\hline $\begin{array}{l}\text { Demographic } \\
\text { Aspects }\end{array}$ & $\begin{array}{l}\text { Racial, social and cultural miscegenation (Freyre, 2009; Ortiz, 2006; } \\
\text { Pires, 2001); mix of cultures (Lucas, 2010; DaMatta, 2001; Bastide, } \\
\text { 1980); racial relationships, cuisine, family life, religiosity (Giraldi et } \\
\text { al, 2011; DaMatta, 2001; Pires, 2001); diversity (SEBRAE, 2002); } \\
\text { language (SEBRAE, 2002); cultural manifestations - samba, } \\
\text { carnival, capoeira, bossa nova (SEBRAE, 2002); fauna and flora, } \\
\text { natural beauties, ecological diversity and exotic fruit (Caponero, } \\
\text { 2007; SEBRAE, 2002; O'neil, 2006; Sutter, 2013; Morace, 2009); } \\
\text { sensuality and beauty of the Brazilian women (Giraldi et al, 2011; } \\
\text { Sutter, 2013; Morace, 2009); }\end{array}$ \\
\hline $\begin{array}{l}\text { Cultural } \\
\text { Dimensions }\end{array}$ & $\begin{array}{l}\text { Lack of hierarchy, fragmentation and lack of cohesion in the social } \\
\text { life (Holanda, 1971); power concentration (Caldas, 2006; Tanure, } \\
\text { 2005); collectivism (Caldas, 2006; Tanure, 2005; Srour, 1994); low } \\
\text { tolerance to ambiguity and instability (Tanure, 2005); masculinity } \\
\text { (Tanure, 2005); Brazilian way (Caldas, 2006; Srour, 1994; DaMatta, } \\
\text { 2001). }\end{array}$ \\
\hline $\begin{array}{l}\text { Economic } \\
\text { Development }\end{array}$ & $\begin{array}{l}\text { Economic rise (Sutter, 2013; Giraldi et al, 2011); corruption, social } \\
\text { inequality, violence (Giraldi et al, 2011; Telles, 2012). }\end{array}$ \\
\hline
\end{tabular}

Source: Authors

The Brazilian way of management is reflected in the performance of Brazilian companies abroad and it also impacts the performance of foreign units based in Brazil (Finestrali \& Garrido, 2010; Maclennan et al., 2014). The strongest aspects of this Brazilian way are power concentration, reinforcing the hierarchical, paternalist and centralizing characteristic (Caldas, 2006; Tanure, 2005); collectivism, with emphasis on personal connections, relationships and protection to the group (Srour, 1994; Tanure, 2005; Caldas, 2006; Debrun, 1990); intolerance to uncertainty, dimension in which the need of laws, controls and standards arises (Tanure, 
2005); and also the masculinity, the least prominent trait, compared to the others, but still reflected in a society that values assertiveness and competitiveness (Tanure, 2005).

\section{FINAL CONSIDERATIONS}

As observed in this study, Brazilianness is part not only of the Brazilian people's life, but also of how the country is understood by the world (Sutter, 2013; Sutter et al., 2014). A particular characteristic is the union of several civilizations in the construction of a country and a national identity (Bastide, 1980). The association of Brazil's image with natural resources, women and sensuality, soccer and carnival is not a surprise and these well-known stereotypes are expected to be present when studying what foreigners based on their own countries think Giraldi et al., 2011; Telles, 2012). The attributes are aligned with some of the values promoted by the Ministry of Tourism (2010), such as the Brasil Brand. However, as Kajihara (2008) reminds, the understanding of these aspects is essential to direct government agencies to works to promote Brazil's image abroad. The author also emphasizes the need to recognize and reinforce aspects that help the country to promote a positive image abroad.

The objective of this research was to reflect on Brazilianness under several views. This research also sought to reflect on and understand what characterizes the Brazilian culture and makes it unique (Ortiz, 2006). Obviously, there is not one single aspect. However, Brazilianness is understood as a set of characteristics of the Brazilian culture and identity that form the country's image. The main characteristics that form the image of Brazil are: racial miscegenation; wide range of cultural manifestations; sensuality and beauty of the Brazilian women; affectivity and hospitality; social inequality; tropical climate; natural beauties; joy of living; spontaneity in human relationships; simplicity in daily life; access to an experience that offers happiness to all (Carnival); color richness and variety; smiles and simplicity of the environment and people; the Brazilian ambiguity (Brazilian way). 
We note in our study that those dimensions show reflections in several dimensions of Brazilian life. Not all of them are positive or neutral; many show criticisms in their categorizations. Looking generally is possible to see that Brazil has a positive image, however there are features that besides recognized by people are not accepted or indulged. An example that can be cited is "Jeitinho Brasileiro". In conclusion, this research was able to identify the elements that place Brazil as an identity that is very different from other country's identities in Latin America and the world. Understanding Brazilianness includes recognizing the differences in the national identity by enabling Brazil to place itself, with all its idiosyncrasies and colors, in a horizontal position and not a subordinate position in the global context (Rosa \& Alcadipani, 2013).

The purpose of this essay was to characterize an objective and critical conception of the meaning of Brazilianness. This is not to dictate meanings. It would be a futile exercise, because there is no consensus on the topic. Rather, the term is subject to plurality and controversy. This is just to clarify essential elements and relationships to a conception that can be fully used in business, tourism and other studies that consider Brasilianness construct as a relevant variable. Such purpose is recognized and explicitly theoretical (Wittgenstein, 1975). Likewise, beside the dimensions chosen, others may be equally relevant.

\section{REFERENCES}

Bastide, R. (1980). Brasil Terra de Contrastes. São Paulo - Rio de Janeiro: Diefel/difusão editorial S.A.

Bhabha, H. K. (2003). O local da cultura. Belo Horizonte: Ed. UFMG.

Burity, J. A. (2002). Mudança Cultural, mudança religiosa e mudança política. In: Burity, J. A (org.). Cultura e Identidade: perspectivas interdisciplinares. Rio de Janeiro: DP\&A.

Caldas, M. P. (2006). Conceptualizing Brazilian Multiple and Fluid Cultural Profiles. Management Research: The Journal of the Iberoamerican Academy of Management, 4 (3), 169-180.

Caponero, M. C.(2007). A imagem do Brasil na Itália: divulgação do patrimônio natural, cultural e antropológico. Dissertação de mestrado (Mestrado em Comunicação), Escola de Comunicações e Artes da Universidade de São Paulo: SP. 
Cavusgil, S. \& Kardes, I. (2013). Brazil: rapid development, internationalization, and middle class formation. InternexT - Revista Eletrônica de Negócios Internacionais da ESPM, 8 (1), 1-16.

Challatas, M., Kramer, T. \& Takada, H. (2008). The impact of national stereotypes on the country of origin effect: A conceptual framework. International Marketing Review, 25 (1), 54 - 74.

Chueke, G. V., Maclennan, M. L. F., \& Borini, F. M. (2014). Modelo Cage e o modo de entrada das multinacionais brasileiras no exterior. Revista de Administração FACES Journal, 13(1), 84-102.

DaMatta, R.(2001). O que faz o brasil, Brasil? $12^{a}$ ed. Rio de Janeiro: Editora Rocco.

Debrun, M. (1990). A identidade nacional brasileira. Estud. Av., São Paulo, $4(8)$.

Finestrali, M. \& Garrido, I. L. (2010). Uso de referências da identidade cultural brasileira no marketing internacional de produtos e marcas de luxo. Revista de Administração FACES Journal, 9 (3), 57-76.

Freyre, G. (1995). Casa-grande \& Senzala: formação da família brasileira sob o regime da economia patriarcal. $30^{a}$ ed. Rio de Janeiro: Record.

Freyre, G. (2009). Modos de Homem \& Modas de Mulher. 2a Ed. São Paulo: Global.

Giraldi, J. M. E., Giraldi, I. M. E. \& Scaduto, A. A. (2011). Brazil's image as social representation process. African Journal of Business Management, $5(1), 8821-8831$.

Gomes, M. S. (2012). A Imagem do Brasil no Exterior e o Turismo: A Operacionalização do Plano Aquarela do Plano em Portugal. Revista Rosa dos Ventos, 4(4), 506-521.

Gürhan-Canli, Z. \& Maheswaran, D. (2000). Cultural Variations in Country of Origin Effects. Journal of Marketing Research, 37(3), 309-317.

Hofstede, G. A. (1980). Culture's consequences. Bervely Hills: Sage.

Holanda, S. B. De. (1971). Raízes do Brasil. 6a ed. Rio de Janeiro: José Olympio.

House, R. J., Hanges, P. J., Javidan, M., Dorfman, P. W., \& Gupta, V. (2004). Culture, Leadership and Organizations. Thousand Oaks: Sage.

Kajihara, K. (2010). A imagem do Brasil no exterior - Análise do material de divulgação oficial da Embratur, desde 1966 até 2008. Revista Acadêmica do Observatório de Inovação do Turismo, 5(3), 1-30. 
Kotler, P. \& Gertner, D. (2002). Country as brand, product, and beyond: a place marketing and brand management perspective. Journal of Brand Management, 9 (4/5), 249-261.

MacLennan, M. L. F., Piccioli, M. L. V., \& Yamasaki, V. E. I. (2014). Aplicação de tipologias de expansão internacional: classificação das vinte empresas brasileiras mais transnacionalizadas. Revista Eletrônica de Estratégia \& Negócios, 7(1), 56-81.

Mariutti, F. G. \& Giraldi, J de M. E. (2012). Análise da Imagem do Brasil por Meio do Anholt Nation Branding Index. Revista Turismo Visão e Ação Eletrônica, 14(1), 67-81.

Martins, P. H. (2002). Cultura autoritária e aventura da brasilidade. In: BURITY, J. A (org.). Cultura e Identidade: perspectivas interdisciplinares. Rio de Janeiro: DP\&A.

Mignolo, W. (2007). La idea de America Latina. Barcelona: Gedisa.

MINISTÉRIO DO TURISMO (2010). GOVERNO FEDERAL (Brasil). Manual de uso 2010 - Marca Brasil. 2010. Available at:

<http://www.turismo.gov.br/turismo/multimidia/logotipos_marcas/galeria_ arquivos_logotipos_marcas/m_brasil_nova_manual_1.pdf $>$ Acesso em: 06 fev 2014.

MINISTÉRIO DO TURISMO (2014). GOVERNO FEDERAL (Brasil). Planos de marketing, 2014. Available at: < http://www.turismo.gov.br/turismo/o_ministerio/publicacoes/cadernos_publicacoes/06pl anos_mkt.html >. Acesso em: 28 fev 2014.

Morace, F. (2009). A globalização e o futuro brasileiro. In: DALPRA, P. (org.). DNA Brasil: Tendências e conceitos emergentes para as cinco regiões brasileiras. São Paulo: Estação das Letras e Cores.

Niss, H. (1996). Country of origin marketing over the product life cycle: A Danish case study. European Journal of Marketing, 30(3), $6-22$.

Ng, S. I., Lee, J. A., \& Soutar, G. N. (2007). Are Hofstede's and Schwartz's value frameworks congruent? International Marketing Review, 24(2), 164-180.

O'Neil, I. (2006). British travellers' image perspectives of Brazil as a tourism destination. Revista Acadêmica Observatório de Inovação do Turismo, 1(4).

Ortiz, R. (2006). Cultura brasileira e identidade nacional. 5a ed. São Paulo: Brasiliense.

Pharr, J. M. (2005). Synthesizing country-of-origin research from the last decade: is the concept still salient in an era of global brands. Journal of Marketing, 13(4), 34-45. 
Pires, M. J. (2001). Lazer e Turismo Cultural. São Paulo: Editora Manole.

Rosa, A. R. \& Alcadipani, R.(2013). A terceira margem do rio dos estudos críticos sobre administração e organizações no Brasil: (re)pensando a crítica a partir do pós-colonialismo. Revista de Administração Mackenzie, $14(6), 185-215$.

Scheider, D. (2005). The Psychology of Stereotyping. New York: Guilford Press.

Schwarz, R. (1987). Nacional por subtração. In: Schawarz, R. Que horas são? Ensaios. São Paulo: Companhia das Letras.

SEBRAE/NA. (2002). Cara Brasileira: a brasilidade nos negócios - um caminho para o "made in Brazil". Brasília: SEBRAE NACIONAL. Available at: <http://www.iets.org.br/biblioteca/Cara_brasileira.pdf>. Acesso em: 06/04/2012.

Schwastz, S. H. (1992). Universals in the content e structure of values: theoretical advances e empirical tests in 20 countries. San Diego: Academic Press.

Srour, R. H. (1994). Formas de Gestão: o Desafio da Mudança. RAE-Revista de Administração de Empresas, 34 (4), 31-45.

Sutter, M. B. (2013). A imagem do país de origem como fonte de vantagem competitiva no mercado internacional: um estudo exploratório no segmento da moda brasileira. Dissertação de mestrado (Mestrado em Administração de Empresas), Faculdade de Administração, Economia e Contabilidade da Universidade de São Paulo: SP.

Sutter, M. B., Polo, E. F., \& Maclennan, M. L. F. (2014). Atributos da imagem do país de origem como fonte de vantagem competitiva: estudo no segmento internacional da moda brasileira. InternexT - Revista Eletrônica de Negócios Internacionais da ESPM, 9(2), 75-93.

Tanure, B. (2005). Gestão à brasileira: somos ou não diferentes? Uma comparação com América Latina, Estados Unidos, Europa e Ásia. 2a. ed. São Paulo: Atlas.

UNCTAD. (2011). World Investment Report (WIR) - UNCTAD. Relatório Anual, 2011. Available at: http://www.unctad.org/Templates/ StartPage.asp?intItemID $=2068$. Acesso em: 21/05/2012.

Usunier, J. C. (2006). Relevance in business research: the case of countryof-origin research in marketing. European Management Review, 3(2), 6073.

Whiteleg, I. (2012). Brazil, Latin America: The World. Third Text, 26(1), 131-140.

Wittgenstein, L. (1975). Investigações Filosóficas. Coleção Os Pensadores. São Paulo: Abril Cultural. 